The International Journal Of Engineering And Science (IJES)

|| Volume || 6 || Issue || 3 || Pages || PP 80-85 || 2017 ||

ISSN (e): $2319-1813 \operatorname{ISSN}$ (p): $2319-1805$

THE IJES

\title{
The Characteristics of Traffic Accidents Caused by Human Behavior on the Road Mayjen Sungkono in Malang City
}

\author{
Dwi Ratnaningsih \\ Departement of Civil Engineering, State Polytechnic of Malang, Indonesia
}

\begin{abstract}
-
The number of motor vehicles increasing impact of the issue of congestion and increasing number of traffic accidents. Roads Maj.Sungkono Kedung Kandang District of Malang has a high accident rate from 2008to 2012 according to data from Malang Police Unit Laka. Results Analysis off act or saffecting the behavior ofthe trafficaccident rateinthe RoadMayjendSungkono Malang include professional act orsaccidents by $87 \%$ is private, thehome city ofthe perpetratorsof accidentsas much as53.07\% came fromMalang, the age ofthe perpetratoraccident $46.296 \%$ isaged26-45years, agepedestriansinvolved $35.484 \%$ age $<17$ th and17-25th ..Based onthe rate of accidentsper yearin theevent of an accidentat maximumie $38.89 \%$.
\end{abstract}

Keywords: Human behavior, traffic accidents, Mayjend Sungkono Street, Malang City.

Date of Submission: 03 March $2017 \quad$ Date of Accepted: 20 March 2017

\subsection{Background}

\section{INTRODUCTION}

Motor vehicles in Malang each year continues to grow. Based on data released by the Treasury Office of East Java Province to mention that in 2010 the number of motor vehicles in Malang reach 292753 units. In the following year, the number of motor vehicles rose to 340753 pieces. That is, within one year of motor vehicles in Malang increased to 48,000 pieces or $16 \%$ per year. It seems that the growing number of motor vehicles that run linearly. It can be seen from the trend in the number of motor vehicles in Indonesia, which continue to experience additional amount. (Source: Provine Income Office Region of East Java). Traffic problems in the system such as congestion and the increasing number of accidents can occur due to poor road user behavior as well as the absence of adequate road infrastructure improvement.

MayJen.Sungkono Street is one District of Kedung Kandang in Malang City including primary local roads. On the road MayJen.Sungkono is becoming increasingly congested road users and the high risk of accidents, because in addition there is a settlement, there is also public facilities such as schools SMAN 6 Malang, SMPN 10 Malang, MI Diponegroro, MTs / MA Hamid Rusdi, TK NU 37, SDN Buring, TK SATAP, SMP Darul Ulum Agung, SMA Darul Ulum Agung, and Integrated University, there are also Terminal Hamid Rusdi, Gor Ken Arok and Housing Cempaka Putih 1.2 and 3.

According to The Law Traffic No.38 of 2004 concerning the Way, the primary local roads are local roads in the area scale local level. At the northern end of the road MayJen.Sungkono District of Kedung KandangMalang has a width of \pm 6 meters with derivatives and climbs high enough, but getting to the south road widening is \pm 7 meters and no derivative and a sharp incline. Roads MayJen.Sungkono District of Kedung Kandang Malang City has a high accident rate from 2008 to 2012, according to data from Malang Police Unit of traffic safety.

The purpose of this study was to determine the effect of human behavior on the characteristics of accidents on roads Mayjend Sungkono in Malang City.

\subsection{Procedures Passes Cross}

\section{BASIC THEORY}

According to The Law of Traffic No.22 the 2009 explained that everyone who uses the road shall behave orderly and prevent things that could obstruct, endanger the security and safety of traffic and road transport, or which may cause damage to the road. Any person driving a motor vehicle on the road shall be driving the vehicle with a fair and full concentration. Motorists should also focus on the safety of pedestrians and cyclists, must also comply with road markings and signs, traffic signal paraphernalia. Motor vehicle drivers should also pay attention to the movement of traffic and the speed that is used to drive a motor vehicle. For vehicles such as trucks hand, be aware of the procedures for coupling and how to coupling

Besides motorists are required to have Vehicle registration number (vehicle registration) / Certificate Try Vehicle (STCK), Driving License (SIM), proof of graduation periodic test and proof of other (certificate of proof of confiscation as a substitute for vehicle registration and so on). In addition to improving the safety of 
four-wheel vehicle drivers are required to wear a seatbelt, while for motorcycle riders wearing helmets compulsory Indonesian National Standard.

\subsection{Definitions Accident}

The Law of traffic No 22 the 2009 states that a traffic accident is an event in the unanticipated and unintended involve vehicles with or without other road users, which resulted in human casualties and / or loss of property.

\subsection{Classification of accidents according to the perpetrator of the accident:}

1. Based on the Professional Actors Accident

a. Government employees

Namely if perpetrator of the accident at work in government agencies

b. entrepreneur

Namely if perpetrator of the accident working outside government agencies

c. Military and Police

Namely if perpetrator of the accident diinstansi military and police work.

\section{Based on Age Performers Accident}

a. Less than or equal to 17 years ( $\leq 17$ years)

Namely if perpetrator of the accident age below or equal to seventeen.

b. Between 17 years to 26 years (17-25 years)

Namely if perpetrator of the accident ranged anatara age of seventeen to twenty-six years.

c. Between 26 years to 45 years (26-45 years)

Namely if perpetrator of the accident ranged anatara age of twenty-six to forty-five years.

d. More than or equal to 46 years ( $\geq 46$ years)

Namely if perpetrator of the accident age above or equal to forty-six years.

a. In the city

Namely if perpetrator of the accident came from the City.

c. As well as Outer City District

Namely if perpetrator of the accident came from outside the city or county.

\section{Based on Age Accident Victims}

a. Less than or equal to 17 years ( $\leq 17$ years)

namely if perpetrator of the accident age below or equal to seventeen.

b. Between 17 years to 26 years (17-25 years)

Namely if perpetrator of the accident ranged anatara age of seventeen to twenty-six years.

c. Between 26 years to 45 years (26-45 years)

Namely if perpetrator of the accident ranged anatara age of twenty-six to forty-five years.

d. More than or equal to 46 years ( $\geq 46$ years)

namely if the perpetrator of the accident age above or equal to forty-six years.

\section{Based on Age Pedestrian Involved}

a. Less than or equal to 17 years ( $\leq 17$ years)

namely if the perpetrator of the accident age below or equal to seventeen.

b. Between 17 years to 26 years (17-25 years)

Namely if perpetrator of the accident ranged anatara age of seventeen to twenty-six years.

c. Between 26 years to 45 years (26-45 years)

Namely if perpetrator of the accident ranged anatara age of twenty-six to forty-five years.

d. More than or equal to 46 years $(\geq 46$ years)

namely if the perpetrator of the accident age above or equal to forty-six years.

\subsection{Characteristics Causes Traffic Accidents}

The traffic generated by the movement of the means of transport, because of their need for the movement of people or goods. The elements of the transportation system are all elements that may influence traffic.

\subsubsection{Road users}

Road users are all those who use the facility directly on a pedestrian street, including the driver, and street vendors. 


\subsubsection{Vehicles}

The main factors that directly cause vehicle accidents are due to design limitations or disability arising from lack of maintenance, adjustments were not good and the destruction of some important components, for example the brakes, tires and lights (FD. Hobs: 1995).

\subsubsection{Road and supporting facilities}
1. Geometric road
2. Pedestrian facility
3. Marka road
4. signs - traffic signs

\subsubsection{Environment}

The environmental conditions surrounding streets provide specific characteristics for the driver. In this case the things that give particular characteristics of the driver are:

a. The state of surrounding road terrain: flat, coastal, beach, mountains, etc.

b. Weather surroundings: sunny, rainy, foggy, dusty, smoky, etc.

c. The state of traffic flow: heterogeneous, homogenya, smooth, jam, etc.

\subsection{Location Survey}

\section{RESEACH METHODS}

Location survey on MayJen.Sungkono Street, District of Kedung Kandang in Malang City.

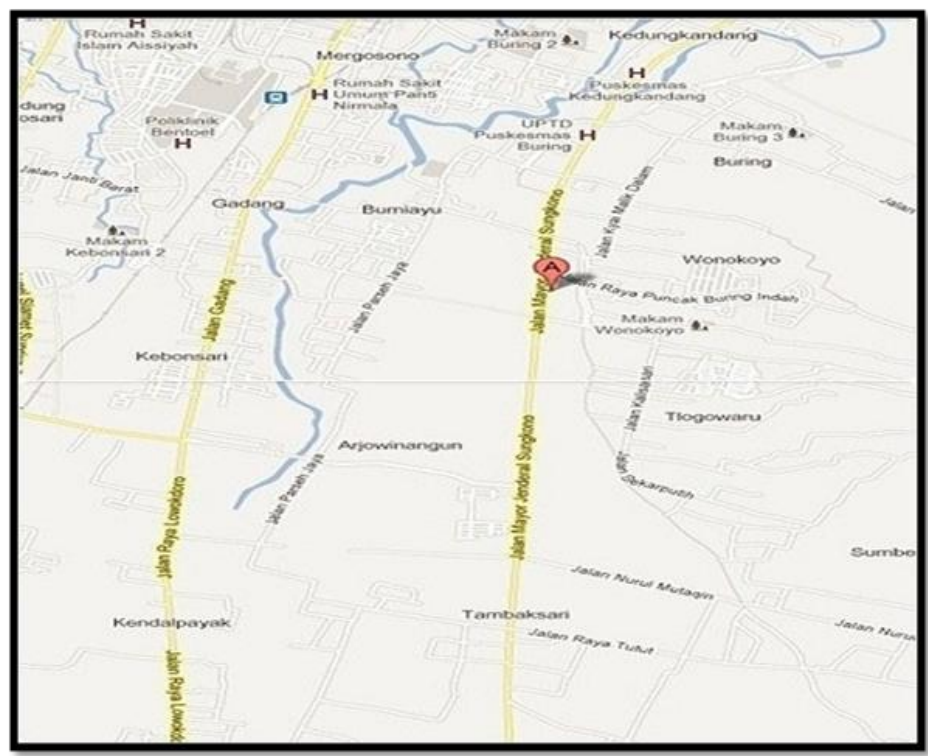

Picture 1 MayJen.Sungkono Street District of Kedung Kandang in Malang City

\section{Source : Goggle Map.com}

\subsection{The data used for this study:}

1.Primary data include: geometric data path

2.Secondary data includes: a data-data traffic accident

\subsection{Analysis of Traffic Accidents}

\section{RESULT AND DISCUSSION}

Perpetrator of the accident greatly affected the maturity of his soul where the age and gender influence on the emotions as well as a reflection in the face of something. Besides education can also affect a person's thought while driving on the highway

Profession perpetrator of the accident is a reflection of the level of intelligence and capability of thinking on the highway, if the profession demanded more critical thinking to a problem, then when driving will be more careful and think further to make decisions while driving their vehicles.

Based on Profession Actor Accident

The number of accidents on the roads MayJen.Sungkono District of Kedung Cage Malang, which occurs by profession perpetrator of the accident can be seen in the following table: 
The Characteristics Of Traffic Accidents Caused By Human Behavior On The Road Mayjen...

Table 1 Classification Table Crash Accident Based on Professional Actors

\begin{tabular}{|l|l|l|l|l|l|l|l|l|}
\hline NO & SPECIFICATION & \multicolumn{2}{l|}{ YEAR } & TOTAL & $\%$ \\
\cline { 3 - 8 } & & 2008 & 2009 & 2010 & 2011 & 2012 & & \\
\hline 1 & GOVERNMENT EMPLOYEES & 0 & 0 & 0 & 1 & 0 & 1 & 1,851852 \\
\hline 2 & TNI-POLICE & 0 & 1 & 0 & 0 & 0 & 1 & 1,851852 \\
\hline 3 & PRIVATE & 7 & 6 & 9 & 19 & 6 & 47 & 87,03704 \\
\hline 4 & STUDENT & 4 & 0 & 0 & 1 & 0 & 5 & 9,259259 \\
\hline \multicolumn{2}{|l|}{ TOTAL } & 11 & 7 & 9 & 21 & 6 & 54 & 100 \\
\hline
\end{tabular}

The number of accidents that occur on these roads by professional actors for the profession as a private accident has a percentage of $87.073 \%$ as much as 47 events

\subsubsection{Originally Based on Performers City Accident}

Originally the town actors will also affect the emotional level perpetrator of the accident Based on data obtained from the Traffic Police unit is Laka Malang City, the number of accidents on the roads MayJen.Sungkono, District of Kedung Kandang in Malang City for the period 2008-2012, which happened by accident offender's home city can be seen in the following table. 2

Table 2 Classification Table Accidents Based on the Home State Actors Accident

\begin{tabular}{|c|c|c|c|c|c|c|c|c|}
\hline \multirow[t]{2}{*}{$\mathrm{NO}$} & \multirow[t]{2}{*}{ CLASIFFICATION } & \multicolumn{5}{|c|}{ YEAR } & \multirow[t]{2}{*}{ TOTAL } & \multirow[t]{2}{*}{$\%$} \\
\hline & & 2008 & 2009 & 2010 & 2011 & 2012 & & \\
\hline 1 & MALANG CITY & 6 & 6 & 2 & 8 & 0 & 22 & 40,74074 \\
\hline 2 & DISTRIICT MALANG & 5 & 1 & 7 & 11 & 5 & 29 & 53,7037 \\
\hline 3 & OUT OF TOWN & 0 & 0 & 0 & 2 & 1 & 3 & 5,555556 \\
\hline \multicolumn{2}{|c|}{ SUB TOTAL } & 11 & 7 & 9 & 21 & 6 & \multirow[t]{2}{*}{54} & \multirow[t]{2}{*}{100} \\
\hline $\mathrm{TO}^{\prime}$ & & & & & & & & \\
\hline
\end{tabular}

Number of most accidents that occur on the road section based on the offender's home city of Malang District accident to the origin of $53.704 \%$ at 29 events,

\subsubsection{Based on Age Perpetrators Accident}

The number of accidents on the roads MayJen.Sungkono District of Kedungkandang in Malang City for the period 2008-2012, which occurs by age perpetrator of the accident can be seen in the following table.

Table3 Classification Table Performer Crash Accident Based on Age

\begin{tabular}{|c|c|c|c|c|c|c|c|c|}
\hline \multirow[t]{2}{*}{$\mathrm{NO}$} & \multirow[t]{2}{*}{ CLASSIFICATION } & \multicolumn{5}{|c|}{ YEAR } & \multirow[t]{2}{*}{ TOTAL } & \multirow[t]{2}{*}{$\%$} \\
\hline & & 2008 & 2009 & 2010 & 2011 & 2012 & & \\
\hline 1 & $<17 \mathrm{TH}$ & 1 & 0 & 0 & 0 & 0 & 1 & 1,851852 \\
\hline 2 & $17-25$ & 5 & 2 & 4 & 9 & 3 & 23 & 42,59259 \\
\hline 3 & $26-45$ & 5 & 4 & 3 & 10 & 3 & 25 & 46,2963 \\
\hline 4 & $\geq 46 \mathrm{TH}$ & 0 & 1 & 2 & 2 & 0 & 5 & 9,259259 \\
\hline \multicolumn{2}{|c|}{ TOTAL } & 11 & 7 & 9 & 21 & 6 & 54 & 100 \\
\hline
\end{tabular}

Perpetrators of traffic accidents occur most commonly at the age of $26-45$ th as many as $46.29 \%$ with an incidence of 25 scene of an accident on the road section within five years

\subsubsection{Based on Age Walking Involved}

Based on data obtained from the Traffic Police unit is Laka Malang, the number of accidents on the roads MayJen.Sungkono District of Kedung Kandang in Malang City for the period 2008-2012, which happened by accident victim's age can be seen in the following table.

Table 4 Classification Table of victims Age Walking Accident Involved

\begin{tabular}{|l|l|l|l|l|l|l|l|l|}
\hline \multirow{2}{*}{ NO } & \multirow{2}{*}{ CLASSIFICATION } & \multicolumn{2}{|l|}{ YEAR } & \multirow{2}{*}{ TOTAL } & $\%$ \\
\cline { 3 - 7 } & & 2008 & 2009 & 2010 & 2011 & 2012 & & \\
\hline 1 & $<17 \mathrm{TH}$ & 4 & 1 & 3 & 1 & 2 & 11 & 35,48387 \\
\hline 2 & $17-25$ & 5 & 2 & 2 & 0 & 2 & 11 & 35,48387 \\
\hline 3 & $26-45$ & 3 & 0 & 1 & 3 & 0 & 7 & 22,58065 \\
\hline 4 & $\geq 46 \mathrm{TH}$ & 1 & 0 & 1 & 0 & 0 & 2 & 6,451613 \\
\hline \multicolumn{2}{|l|}{ SUB TOTAL } & 13 & 3 & 7 & 4 & 4 & 31 & 100 \\
\hline
\end{tabular}

The number of accidents is very high in dominance by pedestrians aged $<17$ years and passers by as much as 17-25 age range $1135.484 \%$ of the incidents occurred on these roads. During the period of last five years. 
The Characteristics Of Traffic Accidents Caused By Human Behavior On The Road Mayjen...

\subsubsection{Based on Age Accident Victims}

Based on data obtained from the Traffic Police unit is Laka in Malang City, the number of accidents on the roads MayJen.Sungkono District of Kedung Kandang in Malang City for the period 2008-2012, which happened by accident victim's age can be seen in the following table.

Table 5 Table Classification of Accidents Based on Age Accident Victims

\begin{tabular}{|c|c|c|c|c|c|c|c|c|}
\hline \multirow{2}{*}{ NO } & \multirow{2}{*}{ CLASSIFICATION } & \multicolumn{5}{|c|}{ YEAR } & \multirow{2}{*}{ TOTAL } & \multirow[t]{2}{*}{$\%$} \\
\hline & & 2008 & 2009 & 2010 & 2011 & 2012 & & \\
\hline 1 & $<17 \mathrm{TH}$ & 5 & 1 & 0 & 1 & 0 & 7 & 6,730769 \\
\hline 2 & $17-25$ & 7 & 3 & 7 & 3 & 0 & 20 & 19,23077 \\
\hline 3 & $26-45$ & 14 & 16 & 4 & 4 & 2 & 40 & 38,46154 \\
\hline 4 & $\geq 46 \mathrm{TH}$ & 11 & 8 & 6 & 8 & 4 & 37 & 35,57692 \\
\hline \multicolumn{2}{|c|}{ SUB TOTAL } & 37 & 28 & 17 & 16 & 6 & 104 & 100 \\
\hline
\end{tabular}

The highest number of accidents is dominated by $26-45$ year-old victim as much as $38461 \% 40$ scene of the accident that occurred on these roads during the period of last five years.

\subsubsection{Based on Age Walking Involved}

Based on data obtained from the Traffic Police unit is Laka in Malang City, the number of accidents on the roads MayJen.Sungkono District of Kedung Kandang in Malang City for the period 2008-2012, which happened by accident victim's age can be seen in the following table.

Table 6 Classification Table Accidents Based on Age Walking Involved

\begin{tabular}{|l|l|l|l|l|l|l|l|l|}
\hline NO & CLASSIFICATION & \multicolumn{2}{|l|}{ YEAR } & TOTAL & $\%$ \\
\cline { 3 - 7 } & & 2008 & 2009 & 2010 & 2011 & 2012 & & \\
\hline 1 & $<17 \mathrm{TH}$ & 4 & 1 & 3 & 1 & 2 & 11 & 35,48387 \\
\hline 2 & $17-25$ & 5 & 2 & 2 & 0 & 2 & 11 & 35,48387 \\
\hline 3 & $26-45$ & 3 & 0 & 1 & 3 & 0 & 7 & 22,58065 \\
\hline 4 & $\geq 46 \mathrm{TH}$ & 1 & 0 & 1 & 0 & 0 & 2 & 6,451613 \\
\hline SUB TOTAL & 13 & 3 & 7 & 4 & 4 & 31 & 100 \\
\hline
\end{tabular}

Number of accidents is very high in dominance by pedestrians aged $<17$ years and passers by as much as 17-25 age range $1135.484 \%$ of the incidents occurred on these roads. This occurs because of the way MayJen.Sungkono there are many schools, both elementary, junior high, or high school, and there is also a university. So that pedestrians aged $<17$ years and the age range of $17-25$ are very much on the road MayJen.Sungkono, especially when going to and from school that coincide with rush hour traffic flow.

\subsubsection{Analysis of Accident Rate Per Year}

An increase or decrease in accidents each year can be measured from the application of the system of traffic safety, if decreased, then the system is applied to reduce such accidents very effective, however, if there is an increase, the system need to hold a review of further reducing the level of accidents which exists.

The following research data presented in the form of tables and histogram accident rate per year:

Table 7 Table Analysis Accident Rate Per Year

\begin{tabular}{|l|l|l|}
\hline YEAR & NUMBER OF EVENT ACCIDENT & PROSENTASE PER YEAR \% \\
\hline 2008 & 13 & 18,056 \\
\hline 2009 & 11 & 15,278 \\
\hline 2010 & 13 & 18,056 \\
\hline 2011 & 28 & 38,889 \\
\hline 2012 & 7 & 9,722 \\
\hline TOTAL & 72 & 100 \\
\hline
\end{tabular}

The data Source: Traffic Police unit is Accidents Malang City

The highest accident that occurred in 2011 with the percentage amount of $38.889 \%$ with an incidence of 28 scene of the accidents

\section{CONCLUSION}

1. Factors affecting the behavior of the traffic accident rate in Street Kota Malang Mayjend Sungkono among other professions perpetrator of the accident, from the city of perpetrator of the accident, aged perpetrator of the accident and the age of pedestrians involved.

2. The number of traffic accidents was highest in 2011 with a percentage of $38.889 \%$ 
The Characteristics Of Traffic Accidents Caused By Human Behavior On The Road Mayjen...

\section{REFERENCES}

[1]. Ratnaningsih Dwi, 2014, Identifikasi Kecelakaan Lalu Lintas Pada Ruas Jalan Mayjen Sungkono Kota Malang , Politeknik Negeri Malang

[2]. Anonym. 1997. Manual KapasitasJalan Indonesia (MKJI). Jakarta :DirektoratJendral Bina Marga.

[3]. Anonym. 2009. Undang-UndangRepublik Indonesia No 22 Tahun 2009, Jakarta :DirektoratJendral Bina Marga.

[4]. Clarkson H. Oglesby, Gary Hicks R. 1988. TeknikJalan Raya EdisiKeEmpat, Jilid I,Jakarta :Erlangga.

[5]. Hobbs, F. D. 1995. PerencanaandanTeknikLalu Lintas. Yogyakarta :Universitas Gajah Mada.

[6]. Morlock, Edward. K. 1998. PengantarTeknikdanPerencanaanTransportasi. Jakarta :Erlangga.

[7]. Munawar Ahmad, 2009,Manajemen Lalu LintasPerkotaan, Yogyakarta, Beta Offset 